\title{
HOW TO AVOID FINANCIAL CRISES
}

\author{
Eleftherios Thalassinos* and Yannis Thalassinos**
}

\begin{abstract}
The recent financial crisis unveiled the major deficiencies and weaknesses of the Eurozone structure. However, almost 10 years after the beginning of the crisis, the Eurozone is still dealing with its effects.

The article discusses some of the reasons of the global crises since the 1980's and focuses on the role of the Credit Rating Agencies ("CRAs") during the recent financial crisis. It presents the methodologies that are used in order to assess country risk, the relevant variables used in their evaluations, the problems they face and suggests possible ways to improve the process at a European level.

The article is organized in five sections as follows: the concept of country risk, platforms for assessing country risk, the determinants of country risk, the reasons behind the recent financial crises and the role of CRAs in the latest financial crisis.
\end{abstract}

Keywords: Financial crisis, country risk, internationalization.

JEL Codes: F2, F32.

\footnotetext{
* Corresponding author: Professor University of Piraeus and Affiliate Professor University of Malta, thalassinos@ersj.eu

**PhD, Investmnt Manager M.A. Kharafi \& Sons, Kuwait City, jthalassinos@gmail.com
} 


\section{INTRODUCTION}

The recent financial crisis was a good lesson on the economic disturbances that a global crisis can cause, especially for the countries of Eurozone and candidate countries. Member - states in Eurozone have given away their right to define their monetary policy and the available options to control their balances are very limited. On the other hand, they have accumulated experience on how to deal with future financial imbalances, if evaluated correctly and on a timely manner. Debates, discussions and extensive research have been conducted in an attempt to convince people about the benefit of an optimum monetary union. However, there is still a long way to shaping a solid and effective union. The European Monetary Union is by definition an incomplete optimum area with big loop holes and missing parts. A few countries, especially the PIIGS (Portugal, Ireland, Italy, Greece, Spain), have paid a heavy penalty for being members of the European Union, because they failed to comply with the prerequisites and policies imposed by the corresponding bodies during the membership period or before (Thalassinos and Stamatopoulos, 2015; Thalassinos et al., 2015; 2014). This study presents views regarding the causes of the recent global financial crises and suggests initiatives on how to avoid them.

According to literature, Foreign Direct Investments (FDI) are closely related to country risk evaluation. Rating companies, namely Standard and Poor's, Fitch, Moody's, as well as specific departments of multinational corporations, are analysing subjectively the evolution of a country's risk. Rating grades appear to be important support-tools in decision-making; however, the provided ratings are used by decision makers as such, without any critical attitude.

The phenomenon of globalization has improved the understanding of country risk, and unpredicted recurring crises stress the fact that the assessment processes have significant shortcomings. Countries like Greece, Portugal, Spain, Cyprus, Ireland, Italy, which still face economic and social problems, are in a delicate situation for reasons presented in this article (Allegret et al., 2016; Grima and Caruana, 2017).

In this context, this article aims to provide answers to the following questions: Are the rating organizations really accurate and objective in their ratings? What are the relevant variables in the analysis of a financial crisis because of a high-country risk? What are the problem areas and how can they be treated? What is the most appropriate approach for assessing country risk? The article is organized in four sections as follows. 


\section{THE CONCEPT OF COUNTRY RISK}

According to OECD, country risk encompasses transfer and convertibility risk (i.e. the risk a government imposes capital or exchange controls that prevent an entity from converting local currency into foreign currency and/or transferring funds to creditors located outside the country) and cases of force majeure (e.g. war, expropriation, revolution, civil disturbance, floods, earthquakes).

The country risk classifications are not sovereign risk classifications and should not, therefore, be compared with the sovereign risk classifications of private credit rating agencies (CRAs). Conceptually, they are more similar to the "country ceilings" that are produced by some of the major CRAs.

The concept of country risk is closely related to economic globalization as a process creating advantages and disadvantages, with the latter generating country risk according to IMF (2005) and for many years, it was considered an opaque, unpleasant fact of life better left in the hands of the IMF and the export credit agencies (Bouchet, Clark, Groslambert, 2003).

The realisation of "political risk" appeared for the first time in literature in the 1960s. Usher (1965) and Root (1968) were among the first authors to use the term. Researchers tried to estimate the risk of investing abroad, using the term "investment climate" (Gabriel, 1966; Stobaugh, 1969). Notwithstanding, as the next decades displayed, the concept of "political stability" in the respective country and how to measure the phenomenon and what the causal forces are, was shown to be more elaborate than was first expected and there is a long way to go before a solution is found. Different approaches on the concept of country risk are shown in Table 1 below:

Table 1: Various Approaches of Literature on Country Risk

\begin{tabular}{|c|c|c|c|c|c|}
\hline Terminologies & $\begin{array}{l}\text { Definition of } \\
\text { risk }\end{array}$ & $\begin{array}{l}\text { Sources of } \\
\text { risk }\end{array}$ & $\begin{array}{l}\text { Nature of the } \\
\text { investment }\end{array}$ & $\begin{array}{l}\text { Historical } \\
\text { perspective }\end{array}$ & Methodology \\
\hline Political risk & $\begin{array}{l}\text { Performance } \\
\text { variance }\end{array}$ & $\begin{array}{l}\text { Sovereign } \\
\text { interference } \\
\text { Environmen }\end{array}$ & $\begin{array}{l}\text { Foreign direct } \\
\text { investment } \\
\text { Banking }\end{array}$ & $\begin{array}{l}1960 \mathrm{~s}- \\
1970 \mathrm{~s}\end{array}$ & Qualitative \\
\hline Country risk & $\begin{array}{l}\text { Negative } \\
\text { outcome }\end{array}$ & $\begin{array}{l}\text { tal } \\
\text { instability }\end{array}$ & $\begin{array}{l}\text { commercial } \\
\text { loans } \\
\text { Portfolio }\end{array}$ & $1980 \mathrm{~s}$ & Quantitative \\
\hline $\begin{array}{l}\text { Sovereign risk } \\
\text { Cross-border } \\
\text { risk }\end{array}$ & & & investment & $1990 \mathrm{~s}$ & \\
\hline
\end{tabular}

Source: Boucher et al. (2003) 
There is a dispute between academics and practitioners with regard to the range of this research domain. In the relevant literature, the terms that are most commonly used are "country risk" and "political risk", when it comes to the concept of doing business abroad. The terms "cross border risk" or "sovereign risk" are used less. The oldest and most frequently encountered term in literature is "political risk". The term "country risk" appeared in literature later in the 1970s. The new term is primarily a better description of the state of the economy, focusing on real factors and emphasising the entire picture. It was used primarily to describe the business environment, and then the banking sector before it became a general term, especially after the consequences of the international debt crisis in the 1980s. Desta (1985) commented that financial experts in international lending institutions choose to use the term "country risk" or "sovereign risk" instead of "political risk". The important aspect of this development is the fact that the political environment is now considered among the factors determining "sovereign risk".

What should be taken into consideration in the relevant literature is the fact that there is a differentiation between risk and uncertainty. When it comes to risk, the result is improbable, but the likelihood of the results is known or can be estimated. On the other hand, the term "uncertainty" refers to a status where the odds are unknown. Investors' target, by way of this concept, is to decrease uncertainty by becoming informed about the risk concerning the profits of the value of the firm, whilst always bearing in mind the variability of the future state of the economy. Consequently, the concept of country risk indicates the support of the investor, by diminishing the incertitude and discovering the changeability potential of profits and the worth of the foreign investment accordingly (Domowitz and Glen, 1998).

Country risk has been divided, in the relevant literature, into six main categories. As defined by Coplin and O'Leavy (1994), country risk is a result of a mixture of risks oriented from several sources. The sources are economic, financial, transactional, institutional or political. Accepting that the correlation between the local economy, together with its political system, the social nature of the economy and the economic structure of the country and the international community is quite important, significant conclusions can be drawn regarding the magnitude of country risk. Although the six types of country risk may not be universally accepted, these notions are inclined to appear in the risk ratings of most companies. To facilitate this study, a short survey of these types of risks focusing on the sovereign risk, are presented below.

Economic Risk: This type of risk emerges from the possibility of harmful changes in basic economic policy targets, such as monetary and fiscal, or a change in competitive advantage of a country, such as decreased resources. 
Economic risk tends to coincide with other types of risks, mostly with political risk, since they both have trade-offs with policy (Coplin and O'Leavy, 1994; Caouette et al., 1998 and Saunders and Allen, 2002).

Transfer Risk: This type of risk emerges when a foreign government decides to confine different types of capital investments. Normally, transfer risk is considered as a characteristic of a country's potential to gain foreign currency, mentioning that in order to earn foreign currency it is required to follow certain policies, whilst it is a very difficult task for most of the weak economies in the Eurozone (Coplin and O'Leavy, 1994).

Exchange Risk: This type of risk contains an unanticipated alteration in the currency regime. Numerous quantitative measures are used to recognise transfer risk and also recognise exchange rate risk, especially when some of the imbalances could be reduced by the devaluation of the currency. This could lead to increasing transfer risk. Moreover, an isolated exchange risk could be assisted by a country's rate of exchange policy. As soon as the policy makers in the respective country try to control the currency system regime in a narrow trading range, it is inclined to realise a higher risk than fixed by the currency board systems regime. In case of a flexible exchange rate regime in a currency's value, it is allowed to fluctuate according to foreign exchange market conditions, whilst they generally support the lowest risk of generating an unexpected opposite exchange rate movement (Coplin and O'Leavy, 1994 and Borio and Parker, 2004).

Location or Neighbourhood Risk: This type of risk issue, in a geographic area, in a country's ally or in countries with common traits, causes spill-over effects. Each country's geographic position is strategic and offers the simplest way to measure the location risk. Location could be specified by a country's international partners, global trading alliances (NAFTA, EU, etc.), the size of the economy, and the boundaries, as well as the interval by financially or politically significant countries or regions (Coplin and O'Leavy, 1994 and Saunders and Allen, 2002).

Political Risk: The origin of the concept of political risk is noteworthy. Significant changes in political institutions stem either from deviations in government controls, social structures or other non-economic factors. The capacity for conflicts, either internal or external, expropriation risk and original political analysis could be included. As far as risk estimation is concerned, many factors should be co-calculated, such as the relationships of various groups in a country, the method for drawing conclusions, the decision-making procedure by government agents as well as the credit-default history of the country (Coplin and O'Leavy, 1994).

Sovereign Risk: Over the past few years, there have been quite a few cases of governments preparing to meet their loan obligations or back down on loans 
they vouched for. Sovereign risk could be related to transfer risk since a government may lack foreign exchange, as a result of unfortunate developments in its current account balances. The sovereign risk is so well-related to political risk that a government may decide not to fulfil its commitments, mainly for political reasons. In the relevant literature, the concept of sovereign risk is described as a separate type, as long as a private lender is confronted with a unique risk in dealing, such as the current financial crisis, and cannot claim a reimbursement from the foreign government unless they have its authorisation (see: Coplin and O'Leavy, 1994; Caouette et al., 1998; Saunders and Allen, 2002; Borio and Parker, 2004 and Scholtens et al., 2004).

A country risk approach depends on the type of state considered or on the nature of the considered agent (Kold, 2011). It should be noted that there is difference between sovereign and country risk. In general, the rating assigned by the analysts to the sovereign risk coincides with the maximum score of state (sovereign ceiling); no local agent does receive a rating higher than that of the sovereign risk. According to some researchers this is not always the right approach. As Meunier and Sollogoub (2005) highlight, during the Russian crisis, Gazprom continued to credit its own debt while the Russian Federation has suspended the payments.

Recent papers have presented new approaches to the country risk concept, and the number of entities that deal with its analysis has increased significantly. Other studies in the last decade (Arteta, 2008; Reihart, 2009; Giordano, 2009) have developed new perspectives according to which risk can be contemplated as the perspective of the economic participants reached by risk creditors. banks, investors (financial or industrial risk), exporters (commercial risk).

\section{ASSESSING COUNTRY RISK}

Institutions that carry out country risk assessment except for the aforementioned CRAs are insurance companies (e.g. COFACE - Compagnie Française d'Assurance pour le Commerce Extérieur); consulting firms (North South Export in France, Business Environment Risk Intelligence); financial publications (Institutional Investor, Euro money Publications) and Banks.

CRAs are well known worldwide and monitor more than $95 \%$ of the government securities market. Their evaluations rank the states in terms of loans and bonds issued. Four major classes of risk are defined (A, B, C, D), for Standard \& Poor's and Moody's, in descending order (from the lowest level of risk, when the country can repay both debt and interest, to the most unfortunate situation). Each class has two more sub-classes (AA, AAA) and two nuance indicators are used, "+" and "-". They point perspectives, the possible development of a note and are the first to change. 
The weighting of the different determinants and the evaluation methodology are unknown to the public. Criteria and factors are divided into two categories; quantitative factors (objective criteria) and qualitative factors (subjective criteria).

The assessment of country risk could be used as a tool in decision making regarding FDI, commercial bank loans for the private and the public sector, portfolio investments and exporting.

However, a strategic investment decision should not be based only the assessment of country risk, but should be linked to the international situation, risk aversion, the perception of uncertainty, the host state characteristics (social and economic situation, labour costs and its qualification), market attractiveness, and the institutional framework.

The determinants of country risk can vary in terms of intensity and duration and it is almost impossible to control within the micro and macro environment (Thalassinos et al., 2015; Duguleana and Duguleana, 2016; Boldeanu and Tache, 2016). A number developed countries are constantly monitoring specific benchmarks and financial performance metrics in an effort to identify warnings in cases of unforeseen negative developments.

\section{THE DETERMINANTS OF COUNTRY RISK}

Currently there are several models of analysis of risk country; the most known are those proposed by BERI (Business Environmental Risk Intelligence), by the U.S. rating agencies (Standard \& Poor's, Moody's, Fitch IBCA, Duff \& Phelps) and by The Economist and Euromoney magazine.

The most common determinants included in these models are the following: Political environment: form of government, democratic participation, quality of succession power, the consensus of economic policy objectives, degree of integration in international economic exchanges, security and defense capacity of the country

Level of public debt: public financial assets, indebtedness of the State, State commitment regarding pension

Pricing: Inflation level, average economic interest rate, exchange policy, level of independence of central bank

Economic structure of incomes: standard of living, income levels and access to health services, existence of market economy, access to resources and their diversity

Flexibility balance of payments: impact of monetary/fiscal policy on national accounts, structure of current account, structure of capital flows

Prospects for economic growth: savings/investment project, rate/ structure of economic growth 
Fiscal flexibility: main budgetary constraints, fiscal policy discretion, pressure on public spending

External debt/liquidity level: currency composition of external debt, importance of banking system, history and payment incidents of extern service

In many cases, country risk problems begin with the deterioration of the fundamental economic and political structure of a state. Warning signals such as excessive debt or declining reserves should be regarded as symptoms of an increased risk. We consider that the analysis of fundamentals is very useful in activities such: identifying the vulnerabilities, finding the origins of problems, assessing difficulties (short-term ones or long-term ones), etc.

\section{RECENT CRISES}

It is almost impossible nowadays, to shield a national economy that operates as part of a globalized world. Any protection mechanism should be designed based on the specific characteristics of each country, however this is not possible due to constraints and obligations associated with supra-international authorities, institutions and organizations regulating the world economy through rules, directives and frameworks that although they were established in a different era are of great importance today.

Several crises of different magnitude have affected the world economy one way or the other over the last few decades. Most of these crises had spread around hitting the weak economies harder than the strong ones. Crises due to nationalization, political reasons, financial failures, sovereign crises, oil or real estate shocks just to mention few of them.

During the Latin American debt crisis of the 1980s - a period often referred to as the "lost decade" - many Latin American countries became unable to service their foreign debt. The Federal Reserve and other international institutions responded to the crisis with a number of actions that ultimately helped alleviate the situation, albeit with some unintended consequences.

Unlike the debt crisis in Latin America, the debt crisis in East Asia in 1997, stemmed from inappropriate borrowing by the private sector. Due to high rates of economic growth and a booming economy, private firms and corporations looked to finance speculative investment projects. However, firms overstretched themselves and a combination of factors caused a depreciation in the exchange rate as they struggled to meet the payments.

The Russian Crisis of 1998 was really an extension of the Asian Crisis. The combination of declining economic output, falling oil prices, enormous budget deficits, and a currency pegged to the rising US dollar overwhelmed the fledgling Russian government. To maintain its peg to the dollar, Russia used its foreign exchange reserves to buy rubles. But as the country gradually depleted 
its foreign exchange reserves, it became clear that Russia would soon run out of reserves. At that point, the Russian government would no longer be able to maintain the ruble's peg to the US dollar. Upon exhausting its reserves, Russia defaulted on its debt and revalued the ruble on foreign exchange markets.

Some examples of more recent crises are the cases of Greece - a public debt crisis, Venezuela - a political crisis, Turkey - a nationalization crisis and Bulgaria - a corruption crisis and more.

The multiplication and diversification process concern not only the country risk, but the economic risks. The liquidity crisis recorded in the financial markets led to easy propagation and to the sovereign debt crisis in 2010 . Globalization and economic liberalization or too much regulation versus regional integration had led to economic inter-dependence.

The openness of the modern countries, where the national dimension is not the main component of the country risk anymore, has made countries more vulnerable to spill over effects of financial crises from other countries. Substantial financial liberalization and deregulation, financial innovation, multiplication and expansion of flows and financial products can lead to speculation.

In addition to the above other concerns are:

$\checkmark$ Extended supply chains - increased vulnerability ("domino effect")

$\checkmark$ Rising and volatile prices (oil, gas) / sovereign debt problem

$\checkmark$ Asset prices collapse / geopolitical risks (Iran, Iraq)

$\checkmark$ Environmental risks / terrorism / new risks / IT risks.

$\checkmark$ Loss of autonomy and increased competition between states result to increased pressure from multinational corporations

$\checkmark$ Attempt to give to supranational institutions greater importance than usual

$\checkmark$ Existence of multiple agreements between international institutions

$\checkmark$ Importance of regional trade blocks (over $65 \%$ of world trade)

$\checkmark$ Network operating enterprises in addition to cultural homogenization vs nationalism

\section{THE IMPACT OF FINANCIAL CRISES ON E-COMMERCE}

As it is pointed out in the work of Ghadami et al. (2010) the recent financial crisis has affected online banking retail business (or B2C e-Commerce) in a negative way. The effect of the crisis can be observed within three different areas of the economy. More specifically, there is less credit available within the economy, which reduces the e-commerce spending and people prefer to save and reduce their expenditures. This behavior leads to falling consumer confidence and sentiment. 
Less credit available: Financial crises are characterized by a shortage in capital funds due to rising uncertainties regarding loans, risks and inbalances in the banking sector. Low credit ratings by CRAs direct capital away from credits including the e-commerce. Therefore, the conclusion by Ghadami et al. (2010) regarding credit is valid.

Increase in saving rates: Limited credit creates conditions for an increase in saving rate since capital is going to save settlements during a financial crisis.

Decline in consumption and falling consumer confidence and sentiment: The above affects negatively consumer confidence and spending.

In the work by Heng (2001) the new banking environment is described as an alternative to transform banking and financial systems. E-Commerce provides a business opportunity for banks to offer innovative products however their attitude to proceed in such activities is positively related to their financial health. During financial crises these opportunities are eliminated and in some cases evaporated because of limited confidence among traders.

\section{THE ROLE OF CRAS IN THE RECENT CRISIS}

Despite readability, rapidity, a recognized degree of simplicity and other advantages, a rating system is not free of a number of subjective elements. However, rating agencies do not provide insights regarding the methodology followed in order to reach to their conclusions. Rating models are not sufficiently explained and scoring systems do not always converge.

The rating agencies have never been far from controversy: at the turn of the millennium they came under fire for giving Enron a clean bill of health right up until the company collapsed in 2001. More recently, they have been subject to criticism in the wake of large losses, beginning in 2007 in the collateralized debt obligation market, that occurred despite products being assigned top ratings. In the US, a Senate report said the agencies deserve some of the blame for the recent financial meltdown. According to the report, the agencies helped banks disguise the risks of the investments they marketed, selling high risk securities with low risk labels

The October 2016 the European Parliament issued a briefing on role of CRAs in the recent crisis. It identifies a marked difference between the recent crises in the USA and the EU. Whilst in the USA the main focus was on the financial crisis, the EU faced both a financial crisis and a sovereign debt crisis, which were interlinked. The sovereign debt crisis was not confined to the euro area, as none of the first three EU countries affected were using the euro. There is evidence that agencies tend to be lax before a bubble is about to burst, only to become very severe once markets head down. Many say that the ratings of a 
number of private and public financial products were too high before the crises, and that the CRAs did not sense any crisis coming. Furthermore, with respect to the European sovereign debt crisis, it has been noted that the agencies did not see or take into account the imbalances in public finances as well as problems with the lack of sustainability of growth models. However, most analysts outside the agencies did not sense the problems either. In the USA, privatesector mortgage-backed securities had been rated in a very favorable manner, contributing to the real-estate bubble and fueling the securitization process. This is one specific area where over-optimistic ratings were a contributory factor to the financial crisis, and where inevitable downgrades accelerated the crisis.

With regard to the European sovereign debt crisis, for many years prior to the crisis the rating agencies did not sufficiently discriminate between sovereigns with divergent levels of accumulated debt. Once that crisis hit, there was a very fast adaptation, with a quick and brutal lowering of ratings. This could be observed very clearly in the peripheral euro- area economies, which enjoyed a rating privilege prior to the financial crisis, which then turned into a penalty as the crisis unfolded. There is controversy about how appropriate the ratings of sovereigns were after that adaptation. Some say that the ratings ended up being too low, thus magnifying the impact of the crises, whilst others estimate that, even after the adaptation, they were still more favorable than they should have been. Over-optimistic rates would have been the consequence of the ex-post bias, as well as prevalent conflicts of interest, whereby CRAs would still have been incentivized to over-rate financial products which, de facto, already were junk bonds, or in the process of becoming precisely that. The successive downgrading of Greece's rates was a factor in the rise of the spreads of long-term government bond yields relative to the German Bund, and contagion to other Member States with less than solid fiscal fundamentals ensued. Euro-area countries like EPRS.

In the case of Greece, although the existence of a set of macroeconomic negative issues should not be denied, it should be pointed out that rating agencies reacted slowly at the beginning, and then brutally and abruptly downgraded the economy to junk status. The same did not happen during the crisis in Asia in 1997; then, the lack of well-drawn warnings (such as evolution of budget deficit, elevated foreign debt, slow capital formation, etc.), allowed the local economies to maintain high ratings. In addition, another parameter that should be considered is whether a country is market friendly or not. Greece has proved over the years that it is a "market friendly" country, whose good faith to international creditors cannot be put in doubt.

Regarding the activity of the rating agencies, some critical remarks can be made based on recent experience: 
$\checkmark$ they did not take into full account the fundamentals of the Greek economy and the measures taken by the EU (the consistent rescue package);

$\checkmark$ they are too critical with countries, which can often negatively influence markets, and less critical with some dangerous financial products;

$\checkmark$ there is maximum concurrence in their market (3 agencies represent more than $97 \%$ of the business);

$\checkmark$ the opacity of the rating process and the level of objectivity sometimes is questionable;

$\checkmark$ the ratings can have a pro-cyclical effect (late and too strong reactions from the agencies) - which can encourage speculation. The pro-cyclical effect is due to the chain of events of this type: downgrade - speculative pressure deterioration of loan terms - higher interest rates - lower investment interest;

$\checkmark$ The threat of imitation and use, without a critical analysis of the assessments made by rating agencies. Often, economic participants use the informational content of the rating and integrate its results, which are considered extremely reliable, in operations and decisions on various global markets. Sometimes, their bad influence may itself lead to pricing dislocations and can affect the behaviour of economic participants.

\section{CONCLUSIONS}

It became clear during the recent crisis that an over-reliance on external ratings - especially those from the CRAs - had the effect of pushing market participants to use mainly external ratings, and similarly to reduce investors' incentives to create their own assessment capacity. Together, these factors resulted in a mechanistic use of external ratings. In the recent crisis, market participants all reacted in a synchronized manner to downgrades, precipitating pro-cyclical effects.

As it was discussed above, following the subprime crisis and the sovereign debt crisis, rating agencies lag behind markets in their judgment. Their business model is flawed as they face major conflicts of interest and are very opaque in their methodologies. Also, the oligopolistic structure of the ratings market provides the three large CRAs with a very strong position in affecting investment decisions and market sentiment.

Several policy options to change the ratings industry have been put forward, including a network of small agencies, a European Rating Agency, or even the delegation of sovereign rating to the ECB. The first option is least preferred, because of the entry costs, coordination problems and the lack of economies of scale. The delegation of sovereign rating to the ECB would in principle be possible, but not preferable as it leads to a conflict of interest within the ECB. That leaves only the option of a European Rating Agency as a way to improve 
rating quality and transparency. However, it also requires high investment costs and time for reputation building

To avoid future financial crises, it is important to take measures to stabilize the economy by implementing sustainable macro-economic policies, to reform the supply side of the economy by improving its structure, to make extra imports due to borrowing only with productive uses (borrowing should simply generate eventually more money), to prevent any form of waste, to reduce the oversized state apparatus, to avoid important policy changes threatening domestic demand, to support consumption expenditures, to improve the effectiveness of the economy to reduce the size of the public sector tax system and to establish a stable political system.

\section{REFERENCES}

Allegret, J.P., Raymond, H. and Rharrabti, H. 2016. The Impact of the Eurozone Crisis on European Banks Stocks, Contagion or Interdependence. European Research Studies Journal, 19(1), 129-147.

Boldeanu, T.F., Tache, I. 2016. The Financial System of the EU and the Capital Markets Union. European Research Studies Journal, 19(1), 60-70.

Borio, C. and Packer, F. 2004. Assessing New Perspectives on Country Risk, BIS Quarterly Review, 2004 (December), 47-65.

Caouette, J.B., Altman, E.I. and Narayanan, P. 1998. Managing Credit Risk, New York: John Wiley \& Sons.

Calverley, J. 1990. Country risk analysis. (2nd ed.), Butterworths, London.

Coplin, W.D. and O'Leary, M.K. 1994. The Handbook of Country and Political Risk Analysis, New York: Political Risk Services, International Business Communications.

Desta, A., 1985, Assessing Political Risk in Less Developed Countries, Journal of Business Strategy, 5(4), 40-53.

Domowitz, I., Glen, J. and Madhavan, A. 1998. Country and Currency Risk Premia in an Emerging Market, Journal of Financial and Quantitative Analysis, 33(2), 189-216.

Duguleana, L., Duguleana, C. 2016. Structural Aspects of the European Union Economy. European Research Studies Journal, 19(1), 93-128.

Gabriel, P.P. 1966. The Investment in the LDC: Asset with a Fixed Maturity, Columbia Journal of World Business, 1(3), 109-119.

Ghadami, F., Aghaie, A., Mohammadkhan, M. 2010. The Impact of Financial Crisis on B2C e-Commerce. I.Busoiness, 2(2), 193-200.

Grima, S., Caruana, L. 2017. The Effect of the Financial Crisis on Emerging 
Markets: A Comparative Analysis of the Stock Market Situation Before and After. European Research Studies Journal, 20(4B), 727-753.

Heng M.S.H. (2001) Implications of e-Commerce for Banking and Finance. In: Schmid B., Stanoevska-Slabeva K., Tschammer V. (eds) Towards the E-Society. IFIP International Federation for Information Processing, vol 74. Springer, Boston, MA

Root, F.R. 1968. The Expropriation Experience of American Companies, Business Horizons, 11(2), 69-74.

Saunders, A. and Allen, L. 2002. Credit Risk Measurement, New York: John Wiley.

Scholtens, B., Frenkel, M. and Karmann, A. 2004. Country Risk Analysis: Principles, Practices and Policies, Berlin: Springer.

Stobaugh, R.B. 1969. How to Analyze Foreign Investment Climates, Harvard Business Review, 47(5), 100-108.

Thalassinos, E., Thalassinos, P. 2006. Stock Markets' Integration Analysis. European Research Studies Journal, 9(3-4), 3-14.

Thalassinos, I.E., Liapis, K. and Thalassinos, E.J. 2014. The role of the rating companies in the recent financial crisis in the Balkan and black sea area. Chapter book in Economic Crisis in Europe and the Balkans, 79-115, Contributions to Economics, Springer International Publishing, DOI: $10.1007 / 978-3-319-00494-5-6$.

Thalassinos, I.E., Stamatopoulos, D.T. and Thalassinos, E.P. 2015. The European Sovereign Debt Crisis and the Role of Credit Swaps. Chapter book in The WSPC Handbook of Futures Markets (eds) W. T. Ziemba and A.G. Malliaris, in memory of Late Milton Miller (Nobel 1990) World Scientific Handbook in Financial Economic Series Vol. 5, Chapter 20, pp. 605-639, ISBN: 978-981-4566-91-9, (doi: 10.1142/9789814566926_0020).

Thalassinos, I.E. and Stamatopoulos, Th. 2015. The Trilemma and the Eurozone: A Pre-Announced Tragedy of the Hellenic Debt Crisis. International Journal of Economics \& Business Administration, 3(3), 27-40.

Usher, D. 1965. Political Risk, Economic Development and Cultural Change, 13(4), 453-462.

Zaman, C., Meunier, B. 2017. A Decade of EU Membership: Evolution of Competitiveness in Romania. European Research Studies Journal, 20(2A), 224-236. 